\title{
PERJANJIAN DAN KONSENSUS DALAM PELAKSANAAN PERENCANAAN PULANG PADA PERAWAT RUMAH SAKIT
}

\author{
Muhamad Rofi' $i^{1,2^{*}}$, Rr. Tutik Sri Hariyati ${ }^{3}$, Hening Pujasari ${ }^{3}$ \\ 1. Program Studi Ilmu Keperawatan Fakultas Kedokteran Universitas Diponegoro, Semarang 50321, Indonesia \\ 2. Program Studi Magister Fakultas Ilmu Keperawatan Universitas Indonesia, Depok 16424, Indonesia \\ 3. Fakultas Ilmu Keperawatan Universitas Indonesia, Depok 16424, Indonesia \\ *Email: rofiimuhamad@yahoo.com
}

\begin{abstract}
Abstrak
Perencanaan pulang dapat memberikan motivasi untuk mencapai kesembuhan pasien. Penelitian ini bertujuan mengidentifikasi faktor-faktor yang mempengaruhi pelaksanaan perencanaan pulang. Desain penelitian ini adalah deskriptif korelasi dengan pendekatan cross sectional. Sampel dalam penelitian ini adalah perawat dan dokumentasi asuhan keperawatan dengan jumlah masing-masing 147dengan purposive sampling dan proporsionate sampling. Analisis riset menggunakan uji Chi Square (signifikansi 5\%) dan uji regresi logistik ganda. Hasil penelitian menunjukkan ada hubungan antara faktor personil perencanaan pulang ( $p=0,01 ; \alpha=0,05)$, keterlibatan dan partisipasi $(p=0,021 ; \alpha=0,05)$, komunikasi $(p=0,008 ; \alpha=0,05)$, perjanjian dan konsensus $(p=0,007 ; \alpha=0,05)$ dengan pelaksanaan perencanaan pulang. Faktor yang paling berpengaruh adalah perjanjian dan konsensus $(\mathrm{OR}=2,361)$. Perawat harus mampu untuk menjalin hubungan, komunikasi, membuat kesepakatan dengan pasien, keluarga, dan tim kesehatan lain.
\end{abstract}

Kata kunci: dokumentasi asuhan keperawatan, pelaksanaan perencanaan pulang, perawat, perencanaan pulang

Abstract

Discharge planning can provide motivation to achieve patient's recovery. The research aimed to identify determinant factors of discharge planning implementation. The study design was descriptive correlation with cross-sectional approach. Research sample was nurses and nursing care documentation 147 each with purposive sampling and proportional sampling. Research analysis used Chi square (5\% significant) and binary logistic regression test. The result indicated that there was relationship between personnel discharge planning ( $p=0.01 ; \alpha=0.05)$, involvement and participation $(p=0.021 ; \alpha=0.05)$, communication $(p=0.008 ; \alpha=0.05)$, agreement and consensus $(p=0.007 ; \alpha=0.05)$ with the discharge planning implementation. The most determinant factor was the agreement and consensus. Nurses should be able to establish network; communicate; making consensus with the patient, family, and other health teams.

Keywords: discharge planning, discharge planning implementation, nurse, nursing care documentation

\section{Pendahuluan}

Perencanaan pulang adalah suatu rencana pulang pada pasien yang ditulis di kertas yang merupakan tujuan perencanaan perawatan pasien (National Council of Social Service, 2006). Perencanaan pulang pasien dapat memberikan motivasi untuk mencapai kesembuhan pasien (Moran, et al., 2005), dapat memberikan dampak terhadap pemendekan lama perawatan pasien di rumah sakit, menurunkan anggaran kebutuhan rumah sakit, menurunkan angka kekambuhan, dan memungkinkan intervensi rencana pulang dilakukan tepat waktu (Swanburg, 2000). Perencanaan pulang pasien dapat menjalin kerjasama dengan penyedia pelayanan keperawatan lebih lanjut (Potter \& Perry, 2005). Perencanaan pulang dapat meningkatkan kepuasan pasien (Shepperd, Parkes, McClaren, \& Phillips, 2010). Perencanaan pulang pasien dapat meningkatkan pengetahuan, kepedulian mengelola perawatan, mengetahui tentang obat-obatan, dan mengetahui tanda-tanda bahaya yang menunjukkan potensial komplikasi (Kleinpell, 2004).

Pelaksanaan perencanaan dipengaruhi berbagai faktor. Menurut Poglitsch, Emery, dan Darragh (2011), terdapat lima faktor yang menentukan keberhasilan proses perencanaan pulang, yaitu faktor personil perencanaan pulang, keterlibatan dan partisipasi, komunikasi, waktu, perjanjian, 
dan konsensus. Keberhasilan pemulangan adalah hal paling penting untuk menjalin kerjasama pada pemulangan klien lanjut usia dari rumah sakit pulang kembali ke rumah (Eija \& Marja-Leena, 2005).

Tujuan penelitian ini adalah untuk mengidentifikasi faktor-faktor yang mempengaruhi pelaksanaan perencanaan pulang pada perawat di Rumah Sakit. Penelitian dapat mengidentifikasi gambaran faktor karakteritik perawat, personil perencanaan pulang, keterlibatan dan partisipasi, komunikasi, waktu, perjanjian dan konsensus yang mempengaruhi pelaksanaan perencanaan pulang pada perawat, mengidentifikasi hubungan faktor karakteritik perawat, personil perencanaan pulang, keterlibatan dan partisipasi, komunikasi, waktu, perjanjian, dan konsensus dengan pelaksanaan perencanaan pulang pada perawat, dan mengidentifikasi faktor yang paling berpengaruh terhadap pelaksanaan perencanaan pulang pada perawat.

\section{Metode}

Pada penelitian ini menggunakan desain korelasi deskriptif dengan pendekatan cross sectional. Sampel penelitian adalah 147 perawat pelaksana, dengan metode pengambilan sampel yaitu total sampling, sedangkan sampel dokumentasi asuhan keperawatan adalah 147 dokumentasi asuhan keperawatan dari ruang rawat inap, dengan metode pengambilan sampel yaitu proporsional sampling. Tempat penelitian yaitu Rumah Sakit X di wilayah Semarang.

Pengambilan data dengan membagikan kuesioner pada perawat pelaksana dan melakukan observasi pada dokumentasi asuhan keperawatan. Setelah data terkumpul dilakukan pengolahan data dengan cara memeriksa data, memberikan kode pada data, memasukkan data ke perangkat komputer dan melakukan pembersihan data. Data dianalisis dengan univariat, bivariat, dan multivariat. Analisis bivariat dengan uji Chi-square dengan tingkat kemaknaan $95 \%$ dan analisis multivariat dengan uji regresi logistik ganda.

\section{HASIL}

\section{Karakteristik Perawat}

Karakteristik perawat yang bekerja di RS X di Semarang adalah berumur antara 20 - 39 tahun $(95,2 \%)$, jenis kelamin wanita $(81,6 \%)$, pendidikan D3 keperawatan $(93,2 \%)$, dan masa kerja antara 1 - 9 tahun $(94,6 \%)$. Status perkawinan mempunyai proporsi yang hampir sama antara yang menikah dan tidak menikah, yaitu 51,7\% dan 48,3\%.

Faktor personil perencanaan pulang mempunyai proporsi hampir sama antara persepsi yang baik (57,1\%) dan kurang (42,9\%), keterlibatan dan partisipasi mempunyai proporsi yang hampir sama antara yang baik $(53,1 \%)$ dan kurang $(46,9 \%)$, komunikasi mempunyai proporsi hampir sama antara yang baik $(53,1 \%)$ dan kurang $(46,9 \%)$, dan perjanjian dan konsensus mempunyai proporsi yang hampir sama antara yang baik $(56,5 \%)$ dan kurang $(43,5 \%)$.

Hasil menunjukkan proporsi persepsi perawat tentang waktu yaitu sebagian besar baik $(83,7 \%)$. Perawat yang melaksanakan perencanaan pulang yang diobservasi pada dokumentasi menunjukkan sebagian besar tidak melaksanakan perencanaan pulang $(61,9 \%)$.

\section{Faktor-Faktor yang Berhubungan dengan Pelaksanaan Perencanaan Pulang}

Tabel 1 menunjukkan tidak ada hubungan yang bermakna antara umur, jenis kelamin, pendidikan, status perkawinan, dan masa kerja perawat dengan pelaksanaan perencanaan pulang ( $\mathrm{p}$ berturut-turut $=$ $0,428 ; 0,433 ; 0,742 ; 0,241 ; 0,260 ; \alpha=0,05)$.

Tabel 2 menunjukkan bahwa ada hubungan yang bermakna antara faktor personil perencanaan pulang, keterlibatan dan partisipasi, komunikasi, serta perjanjian dan konsesus dengan pelaksanaan perencanaan pulang ( $\mathrm{p}$ berturut-turut $=0,01 ; 0,021$; $0,008 ; 0,007 ; \alpha=0,05)$. Selain itu, hasil penelitian juga menunjukkan bahwa tidak ada hubungan yang bermakna antara faktor waktu dengan pelaksanaan perencanaan pulang $(p=0,533 ; \alpha=0,05)$. 
Tabel 1. Hubungan Karakteristik Perawat dengan Pelaksanaan Perencanaan Pulang

\begin{tabular}{|c|c|c|c|c|c|c|c|}
\hline \multirow{3}{*}{ Karakteristik perawat } & \multicolumn{4}{|c|}{ Perencanaan pulang } & \multirow{3}{*}{$\frac{\text { Total }}{n}$} & \multirow{3}{*}{$\mathbf{O R}$} & \multirow{3}{*}{$\mathbf{p}$} \\
\hline & \multicolumn{2}{|c|}{ Tidak } & \multicolumn{2}{|c|}{ Dilaksanakan } & & & \\
\hline & $\mathbf{N}$ & $\%$ & $\mathbf{N}$ & $\%$ & & & \\
\hline \multicolumn{8}{|l|}{ Umur } \\
\hline $20-39$ thn & 88 & 62,9 & 52 & 37,1 & 140 & 2,256 & 0,428 \\
\hline $40-59$ thn & 3 & 42,9 & 4 & 57,1 & 7 & & \\
\hline \multicolumn{8}{|l|}{ Jenis kelamin } \\
\hline Laki-laki & 19 & 70,4 & 8 & 29,6 & 27 & 1,583 & 0,433 \\
\hline Wanita & 72 & 60 & 48 & 40 & 120 & & \\
\hline \multicolumn{8}{|l|}{ Pendidikan } \\
\hline D3 Kep & 84 & 61,3 & 53 & 38,7 & 137 & 0,679 & 0,241 \\
\hline $\mathrm{S} 1 /$ Ners & 7 & 70 & 3 & 30 & 10 & & \\
\hline \multicolumn{8}{|l|}{ Status } \\
\hline Tidak menikah & 40 & 56,3 & 31 & 43,7 & 71 & 0,633 & 0,241 \\
\hline Menikah & 51 & 67,1 & 25 & 32,9 & 76 & & \\
\hline \multicolumn{8}{|l|}{ Masa kerja } \\
\hline 1-9 tahun & 88 & 63,3 & 51 & 36,7 & 139 & 2,876 & 0,260 \\
\hline$>9$ tahun & 3 & 37,5 & 5 & 62,5 & 8 & & \\
\hline
\end{tabular}

\section{Faktor yang Paling Berhubungan dengan} Pelaksanaan Perencanaan Pulang

Hasil analisis dapat disimpulkan bahwa ada tiga variabel yang bermakna yaitu personil perencanaan pulang, komunikasi, dan perjanjian dan konsensus ( $\mathrm{p}$ berturut-turut $=0,025 ; 0,023 ; 0,026 ; \alpha=0,05$ ). Kekuatan pengaruh tampak dari nilai yang terbesar adalah perjanjian dan konsensus $(2,361)$ dan yang terkecil adalah komunikasi $(2,283)$. Hasil uji menunjukkan perawat yang memiliki persepsi baik tentang perjanjian dan konsensus, berpeluang 2,4 kali untuk melaksanakan perencanaan pulang $(\mathrm{OR}=2,361)$.

\section{Pembahasan}

\section{Karakteristik Perawat}

Perawat sebagian besar berusia sekitar 20-39 tahun. Menurut Gibson (1996) umur dapat mempengaruhi kinerja dimana pengembangan karir terjadi pada usia 30 tahun. Umur 30 tahun merupakan tingkat perkembangan manusia yang dikategorikan usia dewasa muda (20-39 tahun) (Papalia, Olds, \&
Feldman, 2009). Pada kelompok dewasa muda ini, termasuk pada pernyataan Simanjuntak (1995), kelompok usia 30 - 40 tahun merupakan usia dengan tingkat produktivitas tertinggi. Menurut Robbins (2006) meyakini kinerja merosot dengan meningkatnya umur. Hasil penelitian ini juga menunjukkan tidak ada hubungan antara umur dengan pelaksanaan perencanaan pulang.

Perawat mayoritas berjenis kelamin wanita. Wanita mempunyai naluri keibuan yang akan menunjang dalam pemberian asuhan keperawatan yang baik, sehingga pelaksanaan standar asuhan keperawatan juga akan berjalan dengan baik. Robbins (2006) menyatakan wanita lebih bersedia untuk mematuhi wewenang dan pria lebih agresif, dan pria memiliki harapan atas keberhasilan lebih besar daripada wanita. Karyawan wanita cenderung lebih rajin, disiplin, teliti, dan sabar (Sopiah, 2008). Hasil penelitian ini menunjukkan tidak ada hubungan antara jenis kelamin perawat dengan pelaksanaan perencanaan pulang. Menurut Farida (2001) bahwa tidak ada hubungan yang bermakna antara jenis kelamin dengan pelaksanaan proses keperawatan. 
Menurut Norman (2004) tidak ada hubungan yang bermakna antara jenis kelamin dengan pelaksanaan pelayanan keperawatan. Selain itu, Supriyatna (2003) menjelaskan tidak ada perbedaan yang bermakna antara jenis kelamin dengan produktifitas kerja perawat.

Perawat sebagian besar mempunyai pendidikan D3 keperawatan. Pendidikan merupakan faktor tidak langsung yang berpengaruh pada kinerja (Ilyas, 2002). Hasil penelitian menunjukkan bahwa tidak ada hubungan bermakna antara tingkat pendidikan dengan pelaksanaan perencanaan pulang. Menurut Hermawati (2002) dan Panjaitan (2002), tidak ada hubungan yang bermakna antara tingkat pendidikan dengan kinerja. Farida (2001) menyebutkan tidak ada hubungan yang bermakna antara pendidikan dengan pelaksanaan proses keperawatan. Hariyati, Afifah, dan Handiyani (2008), menyatakan tidak ada hubungan jenis pendidikan dengan persepsi terhadap pelaksanaan discharge planning.

Perawat sebagian besar sudah menikah. Karyawan yang sudah menikah menilai pekerjaan sangat penting karena dia sudah memiliki tanggung jawab sebagai kepala keluarga (Sopiah, 2008). Robbins (2006) menyatakan bahwa suatu pernikahan akan memaksakan peningkatan tanggung jawab yang dapat membuat suatu pekerjaan yang tetap menjadi lebih berharga dan lebih penting. Hasil penelitian menunjukkan tidak ada hubungan antara status perkawinan dengan pelaksanaan perencanaan pulang. Norman (2004) menyatakan bahwa tidak ada hubungan bermakna antara status pernikahan dengan pelaksanaan pelayanan keperawatan. Farida (2001) menyebutkan tidak ada hubungan bermakna antara status perkawinan dengan pelaksanaan proses keperawatan.

Perawat sebagian besar mempunyai masa kerja 19 tahun. Menurut Sopiah (2008), belum ada bukti, semakin lama seseorang bekerja maka tingkat produktivitasnya akan meningkat. Hasil penelitian menunjukkan tidak ada hubungan antara masa kerja dengan pelaksanaan perencanaan pulang. Farida (2001) menyebutkan tidak ada hubungan yang bermakna antara lama kerja dengan pelaksanaan proses keperawatan. Ini sejalan dengan Sopiah (2008), belum ada bukti semakin lama seseorang bekerja maka tingkat produktivitasnya akan meningkat.

\section{Hubungan Personil Perencanaan Pulang dengan Pelaksanaan Perencanaan Pulang}

Hasil penelitian didapatkan ada hubungan antara personil perencanaan pulang dengan pelaksanaan perencanaan pulang. Menurut Poglitsch, et al. (2011), yang menyatakan personil perencanaan pulang mempengaruhi pelaksanaan perencanaan pulang. Menurut Nosbusch, Weiss, dan Bobay (2011), salah satu tantangan yang dihadapi oleh perawat dalam perencanaan pulang pada pasien dengan perawatan akut merupakan kebingungan peran dan tidak terlihatnya peran staf perawat dalam perencanaan pasien pulang.

Menurut Baron, et al. (2008), tanggung jawab pada perencanaan pulang di rumah sakit adalah tanggung jawab staf keperawatan. Pendapat dari Owyoung (2010), bahwa perawat bertanggung jawab untuk bekerjasama dengan pasien dan penyedia layanan kesehatan di masyarakat, membangun pelayanan rujukan kesehatan, dan memeriksa pasien yang masuk setiap hari, serta memulangkan dengan menentukan yang akan memerlukan perawatan di luar rumah sakit.

\section{Hubungan Keterlibatan dan Partisipasi dengan Pelaksanaan Perencanaan Pulang}

Hasil penelitian menunjukkan bahwa ada hubungan yang bermakna antara keterlibatan dan partisipasi dengan pelaksanaan perencanaan pulang. Menurut Poglitsch, et al. (2011), menyatakan keterlibatan dan partisipasi mempunyai pengaruh terhadap pelaksanaan perencanaan pulang. Frampton (2011) memaparkan bahwa keterlibatan multi profesional secara dini sangat penting dalam perencanaan pulang yang efektif. Menurut Holland dan Heman (2011) bahwa keberhasilan standarisasi proses perencanaan pulang merupakan kerjasama tim multidisiplin. 
Tabel 2. Faktor-faktor yang Mempengaruhi Pelaksanaan Perencanaan Pulang dengan Pelaksanaan Perencanaan Pulang

\begin{tabular}{|c|c|c|c|c|c|c|c|}
\hline \multirow{3}{*}{ Faktor-faktor } & \multicolumn{4}{|c|}{ Perencan aan pulang } & \multirow{3}{*}{$\frac{\text { Total }}{\mathbf{n}}$} & \multirow{3}{*}{ OR } & \multirow{3}{*}{$\mathbf{p}$} \\
\hline & \multicolumn{2}{|c|}{ Tidak } & \multicolumn{2}{|c|}{ Dilaksanakan } & & & \\
\hline & n & $\%$ & $\mathrm{n}$ & $\%$ & & & \\
\hline \multicolumn{8}{|l|}{ Personil perencan aan pulang } \\
\hline Kurang & 47 & 74,6 & 16 & 25,4 & 63 & 2,670 & 0,01 \\
\hline Baik & 44 & 52,4 & 40 & 47,6 & 84 & & \\
\hline \multicolumn{8}{|l|}{ Keterlibatan \& partisipasi } \\
\hline Kurang & 50 & 72,5 & 19 & 27,5 & 69 & 2,375 & 0,021 \\
\hline Baik & 41 & 52,6 & 37 & 47,4 & 78 & & \\
\hline \multicolumn{8}{|l|}{ Komunikasi } \\
\hline Kurang & 51 & 73,9 & 18 & 26,1 & 69 & 2,692 & 0,008 \\
\hline Baik & 40 & 51,3 & 38 & 48,7 & 78 & & \\
\hline \multicolumn{8}{|l|}{ Waktu } \\
\hline Kurang & 13 & 54,2 & 11 & 45,8 & 24 & 0,682 & 0,533 \\
\hline Baik & 78 & 63,4 & 45 & 36,6 & 123 & & \\
\hline \multicolumn{8}{|l|}{ Perjanjian \& konsensus } \\
\hline Kurang & 48 & 75 & 16 & 25 & 64 & 2,791 & 0,007 \\
\hline Baik & 43 & 51,8 & 40 & 48,2 & 83 & & \\
\hline
\end{tabular}

Menurut Han, Barnard, dan Chapman (2009), yang menjelaskan bahwa perencanaan pulang adalah perencanaan pulang dengan keterlibatan dalam pendidikan pasien. Pasien dan pemberi pelayanan (orangtua, wali atau keluarga) dan atau orang lain yang penting juga harus aktif terlibat dan dikonsultasikan dalam perencanaan pemulangan pasien (NCSS, 2006). Pendapat Bull, Hansen, dan Gross (2000), memaparkan bahwa keterlibatan keluarga dalam pelaksanaan perencanaan pulang secara signifikan dapat meningkatkan kepuasan, meningkatkan persepsi mengenai perawatan berkelanjutan, meningkatkan persiapan untuk merawat pasien, dan meningkatkan peran untuk memberikan pelayanan pada pasien.

Pendapat lain dari Baron, et al. (2008), bahwa tanggung jawab terhadap perencanaan pulang di beberapa rumah sakit merupakan tanggung jawab staf keperawatan. Menurut Owyoung (2010), bahwa perawat juga bertanggung jawab untuk bekerjasama dengan pasien dan petugas kesehatan di masyarakat, melakukan rujukan ke petugas kesehatan masyarakat.

\section{Hubungan Komunikasi dengan Pelaksanaan Perencanaan Pulang}

Hasil penelitian menunjukkan ada hubungan yang bermakna antara komunikasi dengan pelaksanaan perencanaan pulang. Menurut Poglitsch, et al. (2011), komunikasi mempengaruhi pelaksanaan perencanaan pulang. Menurut Iyer, Levin, dan Shea (2006), komunikasi antara pemberi pelayanan dan petugas perencanaan pulang adalah penting untuk keberhasilan perencanaan pulang. Swansburg (2000) menyatakan perencanaan pulang termasuk juga memberikan informasi tentang kebutuhan kesehatan berkelanjutan setelah pasien pulang.

Menurut Nosbusch, et al. (2011) bahwa salah satu tantangan yang dihadapi oleh perawat dalam perencanaan pulang pada pasien dengan perawatan akut merupakan intra komunikasi dan komunikasi lintas disiplin dalam perencanaan pulang. Potter dan Perry (2005) menyatakan salah satu langkahlangkah prosedur dalam perencanaan pulang yaitu perawat melakukan konsultasi dengan anggota tim kesehatan lain tentang berbagai kebutuhan pasien setelah pulang. 


\section{Hubungan Waktu dengan Pelaksanaan Perencanaan Pulang}

Hasil penelitian menunjukkan bahwa tidak ada hubungan antara masa kerja dengan pelaksanaan perencanaan pulang. Menurut Poglitsch, et al. (2011) yang menyatakan waktu mempengaruhi pelaksanaan perencanaan pulang. Pasien pulang secara dini juga mempengaruhi waktu yang tersedia untuk perencanaan pulang (Moran, et al., 2005). Pelaksanaan perencanaan pulang adalah bagian dari penerapan standar asuhan keperawatan di rumah sakit. Suhartini, Anggorowati, dan Katili (2003) menyatakan belum lengkapnya fasilitas penunjang seperti buku pedoman Standar Asuhan Keperawatan (SAK) di ruang rawat, kurangnya waktu, dan rumit serta sulitnya pengisian format menimbulkan penerapan SAK tahap pengkajian, diagnosis keperawatan, intervensi, implementasi, dan evaluasi kurang dalam penulisan.

Menurut Nosbusch, et al. (2011) bahwa salah satu tantangan yang dihadapi oleh perawat dalam perencanaan pulang pada pasien dengan perawatan akut adalah waktu dalam perencanaan pulang. Danvers (2011) menyatakan bahwa waktu yang cukup sangat penting untuk perencanaan pulang karena memberikan kesempatan untuk melakukan pengkajian klien, pengembangan dan pelaksanaan perencanaan pulang.

\section{Hubungan Perjanjian dan Konsensus dengan Pelaksanaan Perencanaan Pulang}

Hasil penelitian menunjukkan ada hubungan antara perjanjian dan konsensus dengan pelaksanaan perencanaan pulang. Perjanjian atau konsensus mempengaruhi pelaksanaan perencanaan pulang (Poglitsch, et al., 2011). Perencanaan pasien dimulai dengan merencanakan perencanaan kehidupan klien atau keluarga setelah pulang (Tomura, et al., 2011). WHO (2005) yaitu ketika pasien meninggalkan rumah sakit, perawat harus menekankan perjanjian rujukan sehingga pasien jelas tentang hal-hal yan harus dilakukan. Menurut Tomura, et al. (2011), yang menyatakan membuat perjanjian/ persetujuan pemulangan adalah kategori inti dari proses perencanaan pulang yang dilakukan oleh perawat.

\section{Faktor yang Paling Berpengaruh terhadap Pelaksanaan Perencanaan Pulang}

Faktor yang paling mempunyai pengaruh terhadap pelaksanaan perencanaan pulang pada perawat adalah faktor perjanjian dan konsensus (OR= 2,361). Peluang perawat yang memiliki persepsi baik tentang perjanjian dan konsensus, memiliki peluang 2,4 kali untuk melaksanakan perencanaan pulang.

\section{Kesimpulan}

Ada hubungan antara faktor personil perencanaan pulang, keterlibatan dan partisipasi, komunikasi, perjanjian dan konsensus dengan pelaksanaan perencanaan pulang. Tidak ada hubungan antara faktor karakteristik perawat dan waktu dengan pelaksanaan perencanaan pulang. Faktor yang paling berpengaruh pada pelaksanaan perencanaan pulang pada perawat adalah faktor perjanjian dan konsensus.

Rekomendasi penelitian ini yaitu adanya SOP dan alur yang jelas untuk mengatur peran personil perencanaan pulang, mengatur keterlibatan, dan partisipasi orang-orang yang terlibat dalam pelaksanaan perencanaan pulang, serta mengatur perjanjian dan konsensus dalam pelaksanaan perencanaan pulang. Saran lain yaitu memotivasi perawat melakukan komunikasi dan hubungan profesional dengan teman sejawat, dokter, pasien dan keluarga, serta petugas kesehatan di masyarakat dalam pelaksanaan perencanaan pulang (HW, JS, HP).

\section{Referensi}

Baron, M., Erlenbusch, B., Moran, C.F., O'Connor, K., Rice, K., \& Rodriguez, J. (2008). Best practices manual for discharge planning: Mental health \& substance abuse facilities, hospitals, foster care, prisons, \& jails. Los Angeles: Coalition to hunger \& homelessness. 
Bull, M.J., Hansen, H.E., \& Gross, C.R. (2000). Differences in family caregiver outcomes by their level of involvement in discharge planning. Appl Nurs Res, 13 (2), 76-82.

Danvers, L. (2011). The availability time of discharge planning. American Physical Therapy Association, Clearance Center Inc, 222 Rosewood. (ISSN 1538-6724).

Eija, G., \& Marja-Leena, P. (2005). Home care personnel's perspectives on successful discharge of elderly clients from hospital to home setting. Scand J Caring Sci, 19 (3), 288-295.

Farida, B. (2001). Analisis faktor-faktor yang berhubungan dengan pelaksanaan proses keperawatan di ruang rawat inap RSJHK (Tesis, tidak dipublikasikan). FIK UI, Jakarta.

Frampton, R. (2011). The leads teaching hospitals NHS: Discharge policy. Shetland: NHS.

Gibson, J.L., Ivancevich, J.M., \& Donelly, J.H. (1996). Organisasi: Perilaku struktur, proses (Edisi kelima). (Penerjemah: Soekrisno, A.) Jakarta: Erlangga.

Han, C.Y., Barnard, A., \& Chapman, H. (2009). Emergency department nurses' understanding and experiences of implementing discharge planning. Journal of Advanced Nursing, 65 (6), 1283-1292. Publisher: Wiley-Blackwell.

Hariyati, R.T.S., Afifah, E., \& Handiyani, H. (2008). Evaluasi model perencanaan pulang yang berbasis teknologi informasi. Makara Kesehatan, 12 (2), $53-58$.

Hermawati. (2002). Analisa kepuasan kerja \& hubungan dengan kinerja dalam melaksanakan asuhan keperawatan yang dipersepsikan perawat pelaksana di ruang rawat inap RSUP Dr. M. Jamil Padang (Tesis, tidak dipublikasikan). FIK UI, Jakarta.

Holland, D.E., \& Hemann, M.A. (2011). Standardizing hospital discharge planning at the Mayo Clinic. Joint Commission Journal on Quality and Patient Safety, 37 (1), 29-36.

Ilyas, Y. (2002). Kinerja, teori, penilaian, \& penelitian (Cetakan ketiga). Jakarta: Pusat Kajian Ekonomi Kesehatan, FKM UI.
Iyer, P.W., Levin, B.J., \& Shea, M.A. (2006). Medical legal aspects of medical records. USA: Lawyers \& Judges Publishing Company.

Kleinpell, R.M. (2004). Randomized trial of an intensive care unit - based early discharge planning intervention for critically ill elderly patients. American Journal of Critical Care, 13 (4), 335-345.

Moran, G., Semansky, R., Quinn, E., Noftsinger, R., \& Koenig, T. (2005). Evaluability assessment of discharge planning and the prevention of homelessness. Rockville: WESTAT.

NCSS. (2006). Care and discharge planning: A guide for service providers. Singapore: National Council of Social Service. (Serial No: 032/SDD19/ DEC06)

Norman, R. (2004). Faktor-faktor yang berkontribusi dalam pelaksanaan pelayanan keperawatan di ruang rawat inap RSPAD Gatot Subroto Jakarta (Tesis, tidak dipublikasikan). FIK UI, Jakarta.

Nosbusch, J.M., Weiss, M.E., \& Bobay, K.L. (2011). An integrated review of the literature on challenges confronting the acute care staff nurse in discharge planning. Journal of Clinical Nursing, 20 (5-6), 754-774. Publisher: Wiley-Blackwell.

Owyoung, P. (2010). Role of a nurse in discharge planning. Diperoleh dari http://www.ehow.com/ about_6367124_role-nurse-dischargeplanning.html.

Panjaitan, R. (2002). Hubungan efektifitas kepemimpinan kepala ruang dengan kinerja perawat pelaksana di ruang rawat inap RSPAD Gatot Subroto (Tesis, tidak dipublikasikan). FIK UI, Jakarta.

Papalia, D.E., Olds, S.W., \& Feldman, R.D. (2009). Human development perkembangan manusia (Edisi kesepuluh). Jakarta: Salemba Humanika.

Poglitsch, L.A., Emery, M., \& Darragh, A. (2011). A qualitative study of the determinants of successful discharge for older adult inpatients. Journal of American Physical Therapy Association. (ISSN 1538-6724).

Potter, P.A., \& Perry, A.G. (2005). Buku ajar fundamental keperawatan: Konsep, proses, 
\& praktik (Volume 1, Edisi 4). (Alih bahasa: Yasmin Asih, et al.; Editor edisi bahasa Indonesia: Devi Yulianti, Monica Ester). Jakarta: Penerbit Buku Kedokteran EGC.

Robbins, S.P. (2006). Perilaku organisasi. Edisi kesepuluh. Jakarta: PT. Indeks Kelompok Gramedia.

Shepperd, S., Parkes, J., McClaren, J., \& Phillips, C. (2010). Discharge planning from hospital to home. Cochrane Database Syst Rev, (1), CD000313.

Simanjuntak, P. (1995). Peningkatan produktivitas dan mutu pelayanan sektor pemerintah. Jakarta: Dewan Produktivitas Nasional.

Sopiah. (2008). Perilaku organisasional. Yogyakarta: ANDI.

Suhartini, Anggorowati, \& Katili, M.I. (2003). Analisis penerapan standar asuhan keperawatan di Rumah Sakit Kota Semarang (Laporan penelitian, tidak dipublikasikan). FK UNDIP, Semarang.
Supriyatna, Y. (2003). Hubungan antara gaya kepemimpinan kepala ruang dengan produktifitas kerja perawat pelaksana di Rumah Sakit Pusat Pertamina Jakarta (Tesis, tidak dipublikasikan). Fakultas Ilmu Keperawatan Universitas Indonesia, Jakarta.

Swansburg, R.C. (2000). Pengantar kepemimpinan dan manajemen keperawatan. Alih bahasa Suharyati Samba (Editor Monica Ester). Jakarta: EGC.

Tomura, H., Yamamoto, M.N., Nagata, Murashima, S., \& Suzuki, S. (2011). Creating an agreed discharge: Discharge planning for clients with high care needs. J Clin Nurs, 20 (3-4), 444-453. Doi:10.1111/j.1365-2702.2010.03556.x.

WHO. (2005). Pedoman perawatan pasien. Alih bahasa Monica Ester (Editor edisi bahasa Indonesia: Esty Wahyuningsih, Nike Budhi Subekti). Jakarta: Penerbit Buku Kedokteran EGC. 